University of Wollongong

Research Online

Faculty of Social Sciences - Papers (Archive) Faculty of Arts, Social Sciences \& Humanities

2016

Material inheritances: how place, materiality, and labor process underpin the path-dependent evolution of contemporary craft production

Christopher R. Gibson

University of Wollongong, cgibson@uow.edu.au

Follow this and additional works at: https://ro.uow.edu.au/sspapers

Part of the Education Commons, and the Social and Behavioral Sciences Commons

Research Online is the open access institutional repository for the University of Wollongong. For further information contact the UOW Library: research-pubs@uow.edu.au 


\title{
Material inheritances: how place, materiality, and labor process underpin the path-dependent evolution of contemporary craft production
}

\begin{abstract}
This article explores the historic-geographic evolution of contemporary craft production, with sensitivity to materiality of labor process, product design, and accompanying place mythologies. Craft productionincreasingly interpolated as a form of creative work-is shaped by concerns about retrieving archaic tools and ways of making things, celebrating provenance and the haptic skills of makers, and delivering (and marketing) manual labor process. In contrast to evolutionary economic geography's seeming immateriality and abstraction, attention is drawn to material aspects of place and path dependence that undergird geographies of new craft industries: how labor process evolves, in iteration with technical lockins that stem from production method, product design, and capacities of component materials, but also how legacies of mass manufacturing linger in putatively authentic places-shaping new geographic concentrations. An especially vivid case is explored: a cluster of cowboy bootmaking workshops in El Paso, Texas. Bootmaking has metamorphosed from artisanal to factory to a craft-based creative mode of production. Crucial were continuity in product design and evolution of labor process. So, too, was geography: an iconic borderland city location with historic legacies of labor intensive mass manufacturing; migrant workers with requisite embodied skills; antique tools; and significant stocks of leather, the core input material that must be seen, felt, and smelt by makers before fabrication. I argue for a grounded, critical evolutionary economic geography that requires stronger intersection with labor process, with the cultural logics infusing capitalism, and with greater recognition of material inheritances that are reconfigured in place over successive generations.
\end{abstract}

\section{Keywords}

path, material, underpin, process, inheritances, place, materiality, production, craft, contemporary, evolution, dependent, labor

\section{Disciplines}

Education | Social and Behavioral Sciences

\section{Publication Details}

Gibson, C. (2016). Material inheritances: how place, materiality, and labor process underpin the pathdependent evolution of contemporary craft production. Economic Geography, 92 (1), 61-86. 
Gibson, C. (2016). Material inheritances: how place, materiality, and labor process underpin the path-dependent evolution of contemporary craft production. Economic Geography, 92 (1), 61-86. 
Material inheritances: how place, materiality and labor process underpin the pathdependent evolution of contemporary craft production

\author{
Chris Gibson, University of Wollongong Australia
}

\begin{abstract}
This article explores the historical-geographical evolution of contemporary craft production, with sensitivity to materiality of labor process, product design, and accompanying place mythologies. Craft production - increasingly interpolated as a form of creative work - is shaped by concerns to retrieve archaic ways of making things, to celebrate provenance and the haptic skills of makers, and to render visible (and to market) manual labor process. In contrast to evolutionary economic geography's seeming immateriality and abstraction, attention is drawn to material aspects of place and path dependence that undergird geographies of "new" craft industries: how labor process evolves, in iteration with technical lock-ins that stem from production method, product design and capacities of component materials; but also how legacies of mass manufacturing linger in putatively "authentic” places - shaping new geographic concentrations. An especially vivid case is explored: a cluster of cowboy bootmaking workshops in El Paso, Texas. Bootmaking has metamorphosed from artisanal to factory to a craft-based creative mode of production. Crucial were continuity in product design and evolution of labor process. So too was geography: an iconic borderland city location with historical legacies of labor intensive mass manufacturing, migrant workers with requisite embodied skills, and significant stocks of leather, the core input material that must be seen, felt and smelt by makers before fabrication. I argue for a grounded, critical evolutionary economic geography that requires stronger intersection with labor process, with the cultural logics infusing capitalism, and with greater recognition of material inheritances that are reconfigured in place over successive generations.
\end{abstract}

Keywords: path-dependency, labor process, creative work, skill, authenticity, cultural

\title{
capitalism
}




\section{Introduction}

This article seeks to foreground materiality and its historical evolution in analysis of contemporary craft production. Craft production has garnered renewed interest. In popular discourse craft is linked to the rise of “maker” scenes within western cities previously thought to have eviscerated manufacturing legacies (Causey 2014). Within academic research, craft has been analyzed as a new form of (precarious) creative work (Banks 2010; Thomas et al 2013; Luckman 2015), linked to an economy of “authentic” sign value within “cultural capitalism” (Goldman and Miller 2013). However, what sets craft production apart from many present understandings of creative industries, premised on innovation, is that a source of distinction is the use of “old” production techniques and materials, and slowly accrued haptic skills - referring to those "hand" tasks that emphasize touch and feel - of manual workers. A deeper sense of history lurks in craft production, seldom brought to the surface (Luckman 2012). In this article I countenance the potential for evolutionary economic geography approaches to enable exposition of such embedded histories that give rise to "new" craft industries in specific urban and regional sites. The emergence of contemporary craft production is place- and path-dependent. The geography of "new" craft industries is shaped by how the logics of cultural capitalism (mythologizing “authenticity”) intersect with material legacies from both artisanal and mass manufacturing eras.

The focus on craft also compels consideration of acts of making physical objects (Carr and Gibson 2015). This article accordingly seeks to bring an evolutionary perspective into closer dialogue with analysis of labor process and accompanying materialities. To understand emergent, craft-based forms of production requires a focus on place- and path-dependent histories and materialities of labor process (cf. Frances 1993; Gough 2003), with that in turn 
shaped by political economies of workplace organization and production method, the stability of product design, and affordances of necessary input materials (Hatch 2013). Notwithstanding entanglements with seemingly immaterial knowledge and financial flows, and information technologies, such craft and maker scenes rely upon material elements: they nest in particular urban or regional spaces (with built landscape features and visceral memories of industrial heritage), extract value from the fleshy bodies of workers, use configurations of labor and technology in the physical production process, emphasize quality materials for which provenance is a source of distinction, and ultimately trade in completed physical objects (Warren and Gibson 2013; Patchett forthcoming). How such material aspects evolve in place, over time, and find expression in contemporary urban craft-based production, is the central concern here.

Foregrounding such material and historical aspects is timely, for across advanced economies there is a flourishing fascination with how things are made, and with histories of making (Carr and Gibson 2015). That fascination has encouraged diverse small craft-based enterprises, as well as revivals in artisanal values and trades, "analogue", home and community production practices often thought to be fading into the past (Luckman 2013; Dudley 2014; Tomlinson and Branston 2014). Such "new" craft industries blur traditional distinctions between knowledge and material tasks in labor process, between design and fabrication, and between creative inspiration and repetitive reproduction.

In craft production the perceived persistence of vintage labor processes and product designs becomes a means to add value, and for consumers is a means to cultural distinction (Bourdieu 1984; Luckman 2013). Craft signals the existence of a cultural field within which such designations as "skill”, "handmade”, and "bespoke” are synonymic with creativity, assets for marketing the "authenticity" of finished material goods (Luckman 2015). Adding to the sense of 
"authenticity” are associations with places of manual work - often manufacturing cities that suffered most from previous phases of deindustrialization (Goldman and Miller 2013). Across a huge range of goods emanating from such craft and "maker" scenes - knitted clothing, furniture, ceramics, surfboards, bicycles, ukuleles, craft beers, leather goods - the seemingly cerebral tasks of design, financing, marketing and digital networking are accompanied by physical production and increased visibility of the iterative, haptic tasks of manual production. Yet as I argue here, underpinning geographies of "new" craft industries are also legacies that arise from an era of Fordist mass production. The rise of contemporary craft production blurs distinctions between creative and manufacturing industries, and compels critical reflection on links between inheritance and innovation, between "new" and "old" modes of production.

\section{Towards an evolutionary economic geography of contemporary craft production}

Evolutionary approaches beckon because they illuminate the contingent and path-dependent character of industry development. Present and future economic conditions and arrangements unfurl from previous configurations, a "path-dependent process or system is one whose outcome evolves as a consequence of the process's or system’s own history” (Martin and Sunley 2006, 399). Geographers have contributed significantly to the emerging field, forging links between path-dependency and the importance of space and place - situating networks, industries and knowledge flows geographically, especially at the city-region scale (e.g. Scott 2000; 2006a; Markusen 2010; Greco and Di Fabbio 2014). Over time, systems of technology, organization or product become locked-in, "reverberat[ing] through history, closing alternative paths and validating a particular path (Martin and Sunley 2006, 401). Evolutionary approaches have been 
applied to the complex factors undergirding regional industrial adaptation (Comunian 2011), and to cultural modes of production and creative network formation that persist in place, through time (Warren and Gibson 2014). However, as evolutionary perspectives become increasingly debated and the field more "pluralist" (Hassink, Klaerding and Marques 2014) the challenge is to explicate exactly how geography "influences the process of economic evolution itself” (Martin and Sunley 2006, 397). Among the lingering questions catalogued by Martin and Sunley (2006, 404) are: the degree to which there are different types of path-dependency, under varying circumstances; the intentionality (or otherwise) of path creation and destruction; and whether lock-in effects are necessarily inefficient or negative.

I explore here how geography influences the evolution of contemporary craft production, tracing factors previously underplayed in the evolutionary literature: especially labor process and materiality within manufacturing regions. Through a focus on labor process and materiality, opportunities emerge to situate contemporary craft production within legacies of previous manufacturing activities (cf. Hudson 2005) - with echoes of earlier analysis of embedded labor skills and processes in Italian industrial districts (Scott 1988). Legacies rise to the surface (and, crucially, are mythologized) within craft and maker scenes situated in regions with haunted manufacturing pasts: most prominently, Brooklyn, New York, but also such places as Pittsburgh and Detroit USA, Manchester UK, Rotterdam Netherlands, Gothenburg Sweden, and Melbourne Australia. In such places, industrial legacies resonate - in the urban built fabric as well as in the tacit knowledge possessed by surviving workers. Within a new phase of "cultural capitalism”in which symbolic meaning and sign values infuse commodity production (Lash and Urry 1994; Žižek 2010) - associations between commodity and place have conferred a degree of industrial or working-class authenticity upon "new” craft maker scenes and acts of craft consumption 
(Zukin 2010; Goldman and Miller 2013; Thody 2014). This article accordingly seeks to show how earlier relations, materials, place associations and techniques persist, are mythologized, and evolve into contemporary craft production.

Attempts to theorize new craft industries have tended to draw parallels with creative industries (Luckman 2015). Some aspects of contemporary craft production do indeed map onto "creative" industries discourse, because of the importance of aesthetic content and design flair, and reliance on an artistic mode of labor (Warren and Gibson 2014). In particular, researchers are making the link between craft and creative industries via a focus on precarious work (Banks 2010; Luckman 2013; Barnes 2014; Warren 2014). But craft production also links back to earlier forms of manufacture based on the contiguous production and sale of physical things. Among the ardent consumers of products from "new" craft industries are those typecast as "hipsters," a younger subset of the "creative class" who seek to express dissatisfaction with mainstream consumer culture by fetishizing proletariat values and articulating a "commitment to manual labor" (Goldman and Miller 2013, np). Craft apprizes “traditional” design templates, stable "type forms” (Molotch 2005, 97) bereft of digital features or automated manipulations (Warren and Gibson 2014). My argument is that a critical evolutionary approach focused on labor process and materiality provides a fruitful historical framework to understand "new” craft industries beyond the narrow frame of creative industries, and to garner the importance of material inheritances within places of manual production in shaping new economic geographies.

Such an approach is attuned to deeper run, geographically-contingent and cumulative-causal processes that shape present possibilities (Rantisi et al 2006; Weller 2007). How labor process and materiality unfurl in time and space is relevant both within creative fields such as design, and within physical commodity manufacture (e.g. Müller et al 2009; Bryson and Ronayne 2014), 
illuminating how key sites of expert knowledge are consolidated (Weller 2007). Evolutionary concepts such as embeddedness, network retention and tie selection conventionally used to analyze firm linkages (Glückler 2007) can be brought into a historical analysis of the creative field, of technological change (Dosi 1997), and of the urban landscapes within which distinctive craft labor processes are generated (cf. Scott 2006b). How production processes and required skills among manual workers persist into the age of symbolic and cultural production (rather than simply be annihilated by ceaseless capital mobility) requires further theorization, as does the role played by the physical affordances of input materials, and how popular cultural depictions of manufacturing places (and manual work) infuse contemporary regional craft production.

Materiality - that is, a concern with matter, physical materials, bodies and technologies, and their agentic qualities and interactions - has become a central concern in the humanities in the past decade, linked to an ontological turn in philosophy (Bennett 2010). Via this route discussions of materiality have become especially prominent in cultural geography, as a means to theorize entanglements of animate and inanimate bodies and matter in space (Whatmore 2006; ToilaKelly 2013). In economic and urban geography too, materiality has been applied to creative industries research (Gibson 2005; Hutton 2006; Rantisi and Leslie 2010), object manufacture and distribution (Birtchnell and Urry 2013), transport and mobilities (Latham and McCormack, 2004), resource geographies (Bakker and Bridge 2006), and embodied experiences of work (McDowell 2015). Such thinking emphasizes that economic transformations emerge not in an abstract space of unseen market forces, but through material relations, actors and socio-technical networks (Hudson 2004; 2005; Lee 2006; Mitchell 2008). Critically - the physical and biochemical composition of input materials influences what can be done with them, especially in tactile manual work (Ingold 2010; Carr and Gibson 2015), thus shaping labor process, the 
accrual of haptic skills, the spatial organization of workshops and the regional and global spatial distribution of expertise. Such aspects of materiality linger in city landscapes, in the bodies of manual workers, and become resources that direct new geographies of craft production in an era of cultural capitalism where "authenticity" is a key source of value. Nevertheless, evolutionary economic geography has lagged in its intersection with material ontologies. Here, I accordingly trace materiality in craft-based creative industries via labor process, object design and input materials, in a city-region once home to labor intensive mass manufacturing that has been re-cast as a center for "authentic" craft production.

The article thus sits at the intersection of key literatures on evolutionary economic geography, labor process and materialities - to which I now briefly turn. Two central contributions to these literatures are sought: first, against the degree of abstraction in much evolutionary economic geography, I emphasize the importance of material lock-ins between product design and labor process, and what this means for the continuation of manual hand-based work. Second, I suggest that more-than-human materials, and their capacities and affordances, are a part of such historical inheritances and thus require closer theorization.

This is set against a particular understanding of evolutionary thinking that has become dominant - an abstract, very often quantitative and formal reading of evolutionary processes that comes quite close to spatial science. Nevertheless, in recent years, geographers have pushed for more pluralist and critical evolutionary approaches that are sensitive to grounded context, social institutionalism and questions of political economy (Barnes and Sheppard 2010; MacKinnon et al 2009; Hassink et al 2014). Although evolutionary economic geography remains dominated by normative abstraction, through its emphasis on path dependency it nevertheless suggests potential to document material, technological and socioeconomic inheritances (Hodgson 1994; 
Dosi 1997). The account below thus pursues further engagement with labor process and materiality, opening up avenues for critically engaged pluralism within an evolutionary economic geography approach.

\section{Connecting evolutionary approaches to labor process}

Acts of making are quintessential to craft and maker scenes. This necessarily draws analytical attention to labor process - the "immediate site and material medium of the relation between capital and labour” (Gough 2003, 4), which encompasses “the material processes of production, the allocation of workers to production tasks, the control of workers by management within these tasks, and - crucially - the interrelations between these” (Gough 2003, 3). Matters of the changing process and composition of work have featured strongly in labor geography (Coe 2013; Warren 2014), and in creative industries research (Gibson 2003; Banks, 2010), and are mainstays of research on the shifting fortunes of manufacturing in industrial cities and regions (Gough 2003; Rutherford and Holmes 2014). The growing literature on embodied experiences of work is a related point of connection (Watson 2013; Pratchett forthcoming). However, thus far in evolutionary economic geography labor process has been less extensively theorized than firms, institutions and networks (see for example, Glückler 2007; Boschma and Frenken 2009). In a related critique, feminist economic geographers have similarly argued for an expanded and detailed analysis of everyday, embodied work otherwise "neglected at the expense of a focus on immaterial, high-status employment in knowledge-based economies” (McDowell 2015, 1). The present article responds to such critiques, examining the evolution and materiality of labor process. 
Craft-based forms of manufacture have evolved through long-run transitions in labor process - in the case below, from craft to factory, and back again. Each of these shifts reflects intersecting forces of investment, capital mobility and strategy, technology and labor struggles (Gough 2003). Typically, such shifts have profound implications for the uneven spatial division and distribution of labor (Massey 1984) and for how individual workplaces are organized in ways to govern workers’ bodies and extract value from labor (Barnard and Shapiro 2014; Guéry and Deleule 2014). As work tasks are variously fragmented, centralized or dispersed, deskilled or automated, social and spatial differentiations in employment and unemployment transpire, intersecting with classed, gendered and racialized divisions of labor and impacting upon patterns of urban and regional inequality (Wilson 1991). Echoing Doreen Massey’s (1984) argument, different waves of investment affect the skill sets in the local labor market, and impact on urban built form, leaving a particular configuration of factories, warehouses, institutions, and infrastructure. The existing character of a place interacts with a new layer of investment in a process of mutual determination.

There are resonances here with the literature on path dependency, which ought to be further acknowledged. There are also new layers of complexity unleashed via the intersection with subsequent logics of cultural capitalism. In the case of "new” craft industries, previous phases of investment and withdrawal from manufacturing cities shaped geographies of growth and collapse, but also produced "landscapes of rust belt ruins" that within cultural capitalism are ideal sites "where authenticity can be found" (Goldman and Miller 2013, np). In this circulating economy of signs and "authenticity" the workers once employed in factories mass-producing goods have later gained renewed agency as rare, skilled artisans within a craft-based mode of creative production. The retention of haptic skills is vital, as a practical prerequisite in production 
process. In contemporary craft production haptic skills have also become a key part of the mythology of "making”, conveying a degree of "authenticity" after the collapse of mass manufacturing. Place-specific inheritances of labor process from the manufacturing era thus have a suite of material dimensions involving machinery, workspaces, touch, feel and daily interaction with input materials that are a renewed source of value within a craft mode of production - but also prove a fertile resource for the fetishizing and marketing of manual labor within cultural capitalism.

\section{Foregrounding materials and the making of commodities}

A second conceptual intersection is in relation to input materials. Materiality plays a role in the evolution of craft and maker scenes through product design and assembly methods iteratively related to work tasks, and through the very materials used in commodity manufacture. Crucially, the labor process is "strongly bound up with the type of products it produces" (Gough 2003, 6). Continuity or change in type of product - its design, complexity, and method of construction - is another vector of influence over industrial organization, corporate tactics and spatial structure (Molotch 2005). Shifts in product design, materials and technique are frequently used as tactics to alter the industrial landscape of relations between capital and labor (Frances 1993). There has been increased attention in recent years to the way "things" (bodies, commodities, technologies, nature, buildings) are more than pre-given entities that constrain or enable action, but are themselves products of symbolic and material practices (Cook et al 2011). Literatures on material culture, commodity networks, and actor network theory have contributed to a more complex understanding of the physical qualities of products, combining the bio-chemical 
capacities of component materials, the product's political-economic biography, and subsequent material consumption practices (Cook 2004; Ingold 2010). Craft production - with its emphasis on archaic labor process, haptic skill, bespoke customization and consumer distinction - presents an exemplary case.

Nevertheless, in much evolutionary economic geography thus far, such materiality has at best been implied, and is worthy of further excavation. Some measure of physicality is implied in the concept of technological path dependency (Dosi 1997), and within theories of sunk costs (Melachroinos and Spence 2001) and lock-ins (David 1985). Paul David's much-quoted analysis of the QWERTY keyboard is perhaps the most prominent example (whereby the physical arrangement of a commodity locks-in a particular format as "normal," thereby constraining future innovation potential). Otherwise materiality is seldom brought to the surface as a core concern.

In the case below, key features of product design were locked in during the first phase of mass manufacturing, and old patterns and assembly methods were retained around a stable type form. The most basic lock-in was the persistent use of leather as the key input material - the manipulation of which still needs human hands with considerable haptic skills, and the creative possibilities of which invited cultural capitalist firms to turn a previously standardized product into a canvass for bespoke design creativity in the craft era. Via more-than-human ontologies it becomes possible to view input materials, tools and product designs as interactive or constitutive agents in struggles over labor process; as agents catalyzing affordances and constraining opportunities for firms to innovate, and granting workers some capacity to negotiate the terms and techniques of production (cf. Mitchell 2011; Warren 2014). Through such a focus, this paper also seeks to contribute to a growing analysis of the convergence between creative, craft and 
maker scenes, materiality, skill and work (Jakob 2013; Thomas et al 2013; Warren and Gibson 2013), echoing Andy Pratt’s earlier (2004) call for creative industries research to take seriously their material cultural inputs. If how craft industries evolve is centrally related to labor process, it is also a function of how materials, physical products, production and circulation technologies interact with, constrain and underpin both “mind” and "bodily” work tasks.

\section{A note on empirical methods}

Empirical analysis below draws on qualitative ethnographic research in bootmaking workshops in El Paso from 2010 to 2012, as well as archival work on the bootmaking industry. Consistent with similar studies of craft and creative work (e.g. Watson 2013; Warren 2015), in-depth interviews were conducted with owners of workshops and waged bootmakers within the spaces of production (a total of twenty bootmaking workshops). Invariably, interviews led to "workshop tours” (cf. Warren 2014) - with answers to interview questions interspersed with explanations of production method and technologies while taking time to walk through facilities, inspect materials and learn about key machinery. This workshop setting was pivotal for developing an understanding of production techniques, materiality of tools, leathers, worker skills and the physical spaces of work. Archival work at El Paso City Library, and at both the Smithsonian and Library of Congress in Washington DC, involved sourcing original primary materials relating to the bootmaking industry across 130 years from the 1880s to present (advertisements, industry newsletters, brochures and specialist publications, annual reports, newspaper articles and oral history interview transcripts). Local business directories illustrated the evolution of the bootmaking industry over a century’s time-span and provided tabular and map data. 


\section{Bootmaking: origins and antecedents}

Behind the emergence of El Paso's contemporary bootmaking industry is both a politicaleconomic history of labor-intensive mass manufacturing and the allure and continuing marketability of cowboy imagery in a global cultural economy (Hobsbawm 2013). Bootmaking emerged as an iconic local manufacturing industry for El Paso well after the mythic age of the cowboy and giant northwards cattle drives (1860-1880). Although the accouterments of cowboy style mostly stemmed from this earlier period, with Spanish-Mexican antecedents (GeorgeWarren and Freedman, 2006), the iconic cowboy boot emerged rather later, as a hybrid blend of Civil War-era military boots with vernacular boot-making adaptations, notably in Kansas and Texas (Beard and Arndt 1992). Early design features that settled into a standard template included a sharp point, high-heel and reinforced steel arch (for finding and locking into stirrups) and high vertical tops, with stitching patterns to reinforce the tops and prevent slouching. In the 1860s and 1870s they were largely unadorned work boots. Later, these basic design features would be hyperbolized (in the mass-manufactured, popular culture cowboy era), and then form the basis for artistic expression with bespoke stitching, tooling and overlay designs (in the new craft era).

Early cowboy boots were typically made of thick bull-hide, appropriate for daily agricultural work but impossible to use for delicate stitching or inlay work. Unlike urban boot and shoemaking industries - which had by then already become mechanized, and the source of increased labor tensions (Frances 1993) - in rural America artisanal trade predominated. Scattered towns in Texas, Kansas and Oklahoma featured one or two cobblers or repairing 
workshops where plain custom-measured boots could be ordered. Location was guided by immediate concerns of access for agricultural workers - hence workshops were dispersed along cattle trails and in emerging (colonial) pastoral regions. The mode of production remained artisanal. Cobblers made entire boots piece-by-piece, cutting leathers and stretching parts over lasts carved to the shape of customers' feet, pegging soles and stitching together finished items. El Paso had in the second half of the $19^{\text {th }}$ century a smattering of artisanal bootmakers - but no concentration or cluster of significance.

Genesis of factory production: object design, labor process and formal subsumption

In the first three decades of the twentieth-century production volumes increased from within a selection of these early workshops, though intrinsic production methods remained unchanged. The initial process was typically of an existing small bootmaker, struggling to keep up with growing demand beyond a local catchment, renting larger facilities and, rather than mechanizing or deskilling work tasks, choosing to replicate the custom bootmaking process on a slightly grander scale. In Marxian economic terms, this was more like formal subsumption than a transition driven by capital intensification and task splitting (Barnard and Shapiro 2014). Key to this was the practice - already deeply embedded in cowboy culture - of ordering boots made-tomeasure. Enabling increased volume were new methods for taking custom orders. What once occurred within the confines of a local artisanal bootmaking workshop (a ranch worker being measured up by a bootmaker when passing through town) took place via mail order catalogues that contained information on styles, customization options and measuring instructions. A small 
number of workshops across scattered locations in Texas, Kansas and Oklahoma grew beyond local catchments.

Unlike shoes, which were already "off the shelf” items made in intensive Fordist facilities, the materiality of cowboy boot design and assembly method constrained opportunities to standardize production and deskill work tasks. This was an early form of technological lock-in embedded in the very commodity form. Cowboy boots did not have laces and featured instead high, stiff, wide and increasingly ornately stitched tops. Unlike most other forms of everyday footwear, unless made to measure, cowboy boots became quickly agonizing to wear (if fractionally too small), or simply fell off the foot (if too loose). Some workshops experimented with production using standard sizing (and much later standard sizes would become the norm for cheap mass production, when expectations of perfect fit lapsed), but by and large the nascent factory trade depended on supplying working cowboys with made-to-measure boots.

In El Paso the first upscaled factory of sorts, Rokahr, opened in November 1899, employing 25 people (El Paso Herald 27 November 1899, 8). El Paso-Juarez was then a pivotal staging post in the colonial expansion of North America, a key strategic geopolitical site and cultural and economic “melting pot”. Drawn to the city's frontier lure of new opportunities, Tony Lama, a New York shoemaker with Italian immigrant parents, came to El Paso in 1911. He first worked as a cobbler fixing boots for soldiers at nearby Fort Bliss, one of the United States' largest army bases, and later established a small shoe repair shop. Lama’s business then expanded along with the city itself, evolving into production focused on cowboy boots after World War I, serving the growing western-wear market for ranchers across Texas, New Mexico and Arizona. By 1920 the city's population had boomed to 77,000 and Tony Lama had become its largest bootmaker ( $E l$ Paso Times 19 February 1961, 8). Early factory production in El Paso had begun, based initially 
on replicating artisanal production techniques and retaining the core labor process within expanded facilities.

Mass media, mass manufacturing, increased scale of labor-intensive production

Cowboy clothing as we now know it - snap shirts, hats, chaps, blue jeans, decorative boots further locked into a formula in the 1930s and 1940s when the market for "western” products expanded enormously. That expansion was fuelled by the rise of rodeo, dude ranches, Wild West shows, and visual media, especially film. With the rise of film and radio (enabling the diffusing of cowboy westerns, radio serials and hillbilly music) nationwide demand grew for embroidered shirts and ornate boots, made from "exotic" skins that could be skived, inlaid and subject to more ornate stitching - kangaroo, lizard, snake, alligator - and decorated with sterling silver metalwork, inlaid colors and stitching depicting cacti, bison, eagles and other western motifs (Bull 2000). That spike in demand turned out to be more than a passing fad, and over a period of three decades, from the 1930s to the 1960s, the western wear and bootmaking industries expanded massively in volume, while concentrating geographically in a smaller number of key urban centers in the American West, proximate to core markets: for shirts and jeans, Denver Colorado and San Francisco, California; and for boots, Fort-Worth, Nocona and El-Paso in Texas. These locations all featured newly expanded factories making western wear and boots intended for consumption within and beyond local agricultural workers.

Bootmakers across Texas benefited from the sustained national obsession with cowboy culture. The number of bootmaking factories initially grew rapidly across Texas, including in El Paso but then contracted, as a smaller number of larger firms emerged and consolidated market share 
(Figure 1). By the 1930s, El Paso had become a major import/export and manufacturing city, at the conjunction of three major transcontinental railroads and numerous interstate highways on the US-Mexican border. A borderland location granted fortuitous and evolving trading and transport networks (that would much later fuel enormous narcotics trade as well as low-wage maquiladora production across the river in Juarez - see Wright 1997; Berndt 2013). Also favoring El Paso was the presence of a major pool of skilled but low-cost migrant labor, and an inter-generational, intra-family system of skills transfer among them. Labor availability was fuelled initially in the 1920s by influxes of Mexican refugees after the Mexican Revolution of 1913-1915, which included Mexican entrepreneurs and skilled bootmakers. They brought with them pre-existing regional cultural traditions of Mexican leatherwork - which included an informal, patriarchal trade system whereby fathers and uncles taught sons and nephews how to work with leather.

World War II and the decade following it would then be crucial to the emergence of El Paso as the preeminent center for bootmaking. During World War II, many bootmakers closed operations entirely (Figure 1), though some - most notably Tony Lama - survived because of their proximity to Fort Bliss, shifting to producing GI army boots. The urgency of wartime production encouraged splitting and simplifying work tasks. War fuelled industry concentration and established production processes that enabled subsequent expanded volumes. After the War, both American nationalism and post-war domestic manufacturing ramped up, and a second wave of popular culture cowboys in television, film and country music, along with general prosperity, spurred demand for cowboy apparel.

Intensification and concentration of capital in bootmaking ensued. El Paso's boot factories revisited their pre-war catalogues, and retained their pre-war workforce and designs. Tony Lama 
"just went through the old catalogues to find the designs. Our second and third generation bootmakers already knew how to make them” (Sam Stein, General Sales Manager, Tony Lama, quoted in Hogue 1977, 1c). They also took out loans, built new premises and massively increased volumes. Tony Lama shifted from being a scaled-up artisanal factory gradually expanding its workforce, to a post-war, financialized mass manufacturer, leveraging debt to expand facilities and volumes significantly.

As production increased and volumes began to resemble most other post-war consumer commodities, some mechanization, standardization and task splitting was introduced. In the larger factories machines were introduced that folded leather prior to sewing, that turned boots right-side out after the front and back portions were sewn together, and that speeded up the drying of toe boxes molded into shape with wet leather (a structural and difficult-to-produce feature needed to give cowboy boots their distinctive pointed toes). Nevertheless, the cowboy boot's peculiar materiality still shaped factory expansion (and the labor process within it): bootmaking still could not be completely mechanized and the peculiarities of their design meant continued reliance on hand-lasting, toe box molding and pegging - even as the industry grew exponentially. What resulted was a labor-intensive factory system with some mechanization and task splitting (for instance, separate departments for uppers and soles, for lasting, stitching etc), but nevertheless squadrons of highly skilled craft workers making boots by hand using assembly methods that had changed little since Civil War times. The chain-migration route from Mexico and accompanying patrilineal skills transfer system provided the necessary trained, and cheap, labor.

Firms responded in two ways to the material lock-in of design and dependence on haptic skills: first, through having to retain custom measuring and hand-making, bootmaking companies 
promulgated the idea that made-to-measure cowboy boots were better for the feet and actually more comfortable than store-bought shoes. According to the 1953 Hyer Boots catalog:

The trend all over America to 'Go Western' has created this tremendous demand for cowboy boots... the surprising discovery [is] that people enjoy more comfort and get proper foot support from wearing cowboy boots. New markets have continued to spring up the country over. Western boots have gained widespread acceptance among business and professional men for every-day wear. This is particularly true in the live-stock market centers of Kansas City, St. Joseph, Omaha, Sioux City and Oklahoma City. They have found that no shoe can provide the wearing comfort that a Western Boot does.

Firms thus "invented" need for hand-made boots and created new markets outside of agriculture and dude ranches, among executives, car dealers and law enforcement officers in the South and West who had strong regional loyalties and aspirations to cowboy masculinity (Gibson 2013). By the 1960s, western wear (including boots) had become a settled vernacular form of regular American apparel. Alligator and ostrich skins became de rigueur symbols of social status. In turn, El Paso, Nocona and Fort Worth, where financed factory expansion had been strongest, became centers of boot manufacturing meeting this elevated demand.

Bootmakers also responded to the material lock-in of product design and labor process by attempting to standardize production lines - and by opening up another new burgeoning market for whom different production standards and techniques could apply: children. Television, film, music, toys, fashion and apparel industries conspired in the intense marketing of childhood cowboy heroes such as Roy Rogers for a new baby boomer youth market. Children's boots were marketed as "dress up” items to play “cowboys and Indians," where fit and comfort mattered 
less. In the words of J.T. Dickenson, then General Production Manager at Justin Boot Co., "We call our kids' boots 'grandma and grandpa bait.' They see them in the stores, particularly at Christmas time, and they buy 'em for their grandkids” (quoted in Farman 1996, 213). Capital investment expanded the industry in a smaller number of locations, especially El Paso, to meet such demand, and pre-war companies introduced standardized sizing, mechanization and assembly line methods to supply metropolitan department stores (who carried lines of children's boots).

New, expanded facilities were built and volumes grew accordingly. Work tasks around standard sizing and lines could to some degree be fragmented and made more repetitive. Standard lines meant less judgment on the part of workers regarding how to stretch, layer and combine unique leather pieces for bespoke jobs. Rather than adapting to a different design brief and measurements with each pair, workers replicated a smaller number of designs on a mass scale. Tasks were broadly separated and staff reorganized into lasting departments and ornate stitching teams (Figure 2). Wooden lasts were no longer in each case carved for individual customers, but were held as a stock of standard foot shapes (with fiberglass resin lasts eventually superseding wood-carved lasts in the 1970s).

Nevertheless the material lock-in effect of boot design compelled some degree of labor intensity. Notably, elements of artisanal labor process remained the norm for made-to-order boots - which were still popular among ranchers, car dealers and boardroom management folk. Custom boots were still made from a set number of interlocking pieces, with hand-made toe boxes, were lastmolded and dried and had soles pegged in the traditional method. Family bootmakers thrived in this era in El Paso and elsewhere, and later became legends of the collector scene (for example, James Leddy and Dave Little). But even within the largest factories employing thousands of 
leatherworkers, skilled leatherwork persisted. Wage differentials compared with the Northeast and mid-West made it attractive to new investors, who located there in the 1960s and 1970s. Cowtown Boots moved to El Paso from Fort Worth in 1968 and opened a 100,000 square foot factory in 1977; Justin Boots opened its factory in El Paso in 1972 and expanded it again in 1973; Lucchese moved from San Antonio to El Paso in 1977.

But also, crucially, the region contained the largest pool of bootmaking skills, and had deeply embedded social networks and regional cultural traditions to feed it. The growing factory scene in El Paso accordingly deepened the city’s skilled migrant labor pool. Family and community networks further south into Mexico triggered further chain-migration into El Paso, and commuters increasingly crossed the border daily from Juarez to work in bootmaking factories (Martínez 1978). Class and ethnicity intersected in their depiction as "ideal” workers: skilled, but cheap, and connected to strong historical values of family and artisanal craftsmanship (cf. McDowell 2008).

Essential skills with leather were embodied in these workers and could not be easily mechanized. Tony Lama admitted after a Customs probe that it had subcontracted some of its ornate stitching to firms across the border in Juarez, Mexico in order to lower labor costs (Pruitt 1976). But there was a limit to deskilling. Again the material lock-in of the boot design, and the qualities of the material itself - fine leather - made labor intensity and skill essential. Skilled bookmakers knew how to best position and how far to stretch a skin over a last, how to skive which kinds of leathers into wafer thin sections for inlay work, which parts to use on hardwearing heels and vamps, which skins to line the uppers against which human skins rub, which kinds of snake or lizard skin to use as inlay for decorative purposes. Such tactile knowledge had accrued slowly, and haptically, as "muscle memory" in the hands (and via smell, in the nose) through repeated 
exposure and practice (cf. Hockey and Allen-Collinson 2009). While the production process could be broken down into specialized stages, and wage rates remained low compared with other parts of the United States, machines could not replace the core haptic knowledge of how to manipulate a lively and inconsistent organic material.

The factory system, and skilled workforces, thence expanded in tandem. In 1942, Tony Lama employed 42 people (El Paso Times 24 September 1942, 8). By 1961 Tony Lama’s 130 workers were hand-making 250 boots daily; by early 1970s this had increased to 600 workers making 2,000 pairs daily (El Paso Times 29 February 1979, 1-D); and by 1977, 1200 workers were producing 3,400-3,500 pairs of boots daily (Hogue 1977). Even by the late 1970s, only 30 percent of the total bootmaking process had by then been mechanized. Nine large boot manufacturers had consolidated in the El Paso area, through relocations, mergers and acquisitions, employing some 1700 workers (Hogue 1977). At its height, Tony Lama, with over 580,000 backordered pairs of boots it could not supply on time, doubled the size of its El Paso factory, employing over 1,000 new workers. By 1981, fueled by the “urban cowboy” fad unleashed by the eponymous John Travolta film, Tony Lama were making a million pairs of boots annually in this largely labor-intensive method (El Paso Times 31 December 1980, A-1). The city’s major newspaper, the El Paso Times, proudly declared the city “the cowboy boot capital of the world" (Burchell 1977, B1).

\section{Crisis and creative renewal}

A combination of external events in the mid-1980s and key decisions within the industry nevertheless conspired to bring huge change. By August of 1982 the "urban cowboy" trend had 
faded. Firms that had banked on endless expansion were burdened with debt, and with excess inventory. Justin Boots Co. closed its high-end exotic boot factory at the end of that same year, and Tony Lama laid off 200 workers, then put the company up on the market for sale (El Paso Times 16 December 1982). By 1986 the company was making an annual $\$ 500,000$ loss, with sales bleeding by $\$ 11$ million p.a. (El Paso Times 26 March 1986). One surviving current bootmaker remembers:

Of course the cowboy boot business went crazy [with the Urban Cowboy fad], and they were selling the worst looking stuff you've ever seen. All the big companies like Justin and Tony Lama... they all gobbled up all these little boot makers... Justin built a brand new factory in El Paso that turned out 3,500 pair a day... they were just pouring these boots out. And then all of a sudden the craze went out, the people quit selling cowboy boots. Once you had two or three pair that'll last you a while, right? All these companies started scrambling for market share or for shelf space. They had all this infrastructure and all these people hired, and all of a sudden, well how do they keep shelf space? The quality went down, the prices went down... they just ruined the boot business. (Interview with author, April 2010)

Another consequence of the bust was that the off-the-shelf side of the western wear industry supplying the low-price point agricultural and children's markets - headed largely offshore, to China, as well as deeper into neighboring Mexico. Chinese subcontractors emphasized mechanization, Mexican factories had sufficient, but much cheaper leatherwork skills. In a scramble to survive, the biggest factories, including El Paso's Tony Lama, participated in what one bootmaker described as "a race to the bottom," seeking to cut costs and automate production in order to maintain market share. 
Competitive pressures for the first time in the industry's history forced a widespread, and fundamental shift away from craft-based production methods. In Mexico and China, soles were glued rather than stitched onto vamps; new computer-driven sewing machinery enabled rapid stitching of ornate uppers; staples replaced wooden pegs; plastic replaced leather toe boxes; and poorer cow leather from lowest-cost abattoirs and tanneries (with highly suspect environmental and animal ethics practices) predominated. Corners were cut everywhere in manufacturing technique to make them comparable in price with sneakers. The market for made-to-measure and exotic boots contracted sharply, and cheap imported boots in standard sizes (as well as new designs, such as lace-up "Roper” boots, that eschewed the need for bespoke measurements, and thus higher levels of artisanal skill) flooded the US market. The retail environment shifted too: mom and pop western-wear stores flailed, as new boot barns emerged in big box warehouses across the American West on interstate junctions. A distinctly American regional craft-based and labor-intensive form of making looked like heading the way of countless other domestic manufacturing sectors: obliterated by competitive pressures and mobile capital's ceaseless search for profits.

The plot twist was that the industry - although heavily contracted from its mass manufacturing height in the late 1970s and early 1980s - was not entirely annihilated. In a few places throughout Texas, and especially El Paso, bootmaking workshops and some factories have survived, cementing a niche for high quality boots made-by-hand and made-to-measure. Two factories in El Paso - Lucchese and Tony Lama - at the time of writing remain open, within a stratified corporate marketing strategy. Their lower-cost lines source production in Asia and Mexico, while El Paso plants service the international market for high-end, hand-made boots of fine leather - using skilled bootmakers who remain in El Paso. The format of labor-intensive 
mass production that typified the 1960s bootmaking industry survived in scaled-back form, rebranded as a high-end, luxury product. Another long-time but smaller factory, J.B. Hill, survived the contraction and continued to make high-end boots using a combination of high-skilled labor and limited task splitting.

Meanwhile, new interest in the heritage of bootmaking, the Americana collector scene, and the possibilities of selling customized vintage and retro boots via the Internet led other smaller workshops and solo artisans to commence operations or to move to El Paso. In the growing field of cultural capitalism, El Paso’s borderland, Tex-Mex identity conveyed vital “frontier authenticity” (DeLyser 1999). New companies emerged from the personal passions of individuals out of a nationwide Americana collector/designer scene (itself a product of the rise in the 1990s of an aestheticized "retro" craze). Fashion industry entrepreneurs moved from California and the mid-West to set up shop in El Paso - a move explained by key proximities to leather traders and skilled labor, but also to the city's Wild West mythology and status as the “authentic” home of the industry (Gibson 2014). Other small workshops were established by local Hispanic families with long histories in the industry - skilled bootmakers who once worked for a wage in the Tony Lama or Justin factories, who now became craft-based creative microentrepreneurs.

Emergence of a craft cluster: retention of artisanal labor, and remnant machines and materials

In this contemporary craft-based and customized form of manufacturing, it is important that the boots are seen as made the old-fashioned way. Such boots are marketed as living remnants of a small town, pre-modern, pre-Fordist manufacturing technique, things made well by human hands 
(cf. Hockey and Allen-Collinson 2009; Warren and Gibson 2014). Workshops purposely hold onto archaic production techniques such as hand-pegging soles and personalizing lasts (foot molds) that are kept on file for future reference.

In a manner that inverts theories of innovation, they have also held onto, revived and inherited old machinery from both the artisanal and mass manufacturing eras - not just because of its intrinsic authenticity, but because skilled workers know how to use and maintain it, and it is simply better quality equipment. Such machinery became surplus to requirements with the contraction of mass manufacture, and was readily available at low cost (or in some cases was "handed down” gratis) to those bootmakers who persisted and remained in El Paso as small operators. Lucchese still use a Singer Manufacturing Zig-Zag machine for inside stitching that is over 110 years old. Tres Outlaws purposely purchased antique bootmaking machinery from the deceased estate of a nearby bootmaker to "improve” on newer commercially available equipment. Among the skills cherished by workshop owners are the abilities of bootmakers to also service and fix the old machines, most of which are pre-WWII vintage.

Unlike in the factory era, where firms had struggled with stable type form and the need for haptic skill, and sought to improve efficiencies of production line, with standardized lines and sizes, in the new craft era workshops are run by people who view themselves as “creative” people with artisanal values, seeking to carve a living from a personal "passion” rather than chase maximum profits at all costs (cf. Molloy and Larner 2013; Dudley 2014). Solo artisans especially tolerate low wages, justifying income instability as allowing a creative "life in boots” (cf. Warren 2014). The product's material shape and dimensions have provided a template for new and "retro" artistic expressions. High, tapered tops have become canvasses that enable unique designs (supplied by customers, or selected from a wide range of options and customization possibilities 
from online catalogs, or developed by in-house designers or bootmakers in consultation with the customer). New painted leather techniques (pioneered by Rocketbuster, a company with LA fashion industry origins) and metal inlay possibilities (notably by Tres Outlaws) enabled designs to become ever more diverse and expressive. Whole landscapes (usually Western), complex pictograms or personal biographies could now be depicted in leather (for examples, see https://www.facebook.com/ROCKETBUSTERboots and https://www.facebook.com/falconheadstore). Orders for weddings, college graduation souvenirs or significant birthdays became common. The revival of craft production has ushered in what collectors now describe as a new "golden age" of cowboy boot creativity.

This level of customization, retention of antique equipment and emphasis on manual, hand-made production has effectively capped firm size. The highest-end custom bootmakers - Tres Outlaws, Rocketbuster, JB Hill, Stallion - employ between 6 and 20 staff and focus on intricate inlay, artful design and vintage designs for collectors, musicians, media personalities and actors. Rocketbuster currently makes only about 10 pairs of boots per week. While ostensibly manufacturing firms with small runs of craft-based physical production, they have increasingly embraced selected logics of creative work. They emphasize creativity and originality in design and the central role of the bootmaker as artisan/genius (cf. Sennett 2008). Necessary skills were embedded in El Paso (to use a phrase from evolutionary network theory), but were manifest literally in the bodies of craftspeople - in their hands.

Accordingly, much is made of manual skill in marketing material. At J.B. Hill "we have assembled the finest craftsmen and deliver to them each morning only the highest grades of leather. At that point, we're in their hands” (J.B. Hill Boot Company 2010, 14). The names of bootmakers and places of production are proudly labeled on boots, and in brochures. Facebook 
sites and You Tube video clips profile makers and celebrate their skills - provenance assured. Communities of fandom are cultivated via social media. Customers are accumulated as social media friends on a first-name basis, and encouraged to share photos of their boots.

Aestheticization and the visible performance of identity from wearing unique boot designs are paramount. Deep networks have been generated into other creative sectors (notably film and television) in ways reminiscent of Tom Mix and Roy Rogers many decades previously: supplying attention-grabbing boots for New York fashion shows, Hollywood film stars, heavy metal bands and country singers. Place association in bootmaking operates via connection with El Paso’s history of borderland hedonism and Wild West popular culture connotations (cf. Walker 2007), and with the industry’s artisanal past.

Because volume and subsequent markets are limited, emphasis is placed instead on high-cost materials, rare labor techniques (such as tooling, an ornate leather carving technique which is the most highly paid leather craft) and design intensity. Survival is enhanced by agglomeration tendencies associated with a key interdependency: a tacit agreement among El Paso bootmakers to cross-refer customers to each other's respective subcultural niches. Workshops accordingly specialize in biker tattoo designs, Goth, rock and Hollywood, art boots, vintage, hipster, patriotic, Tex-Mex, authentic 1940s design reproductions, or suave cosmopolitan - rather than copy each other's work. According to the co-owner of Rocketbuster Boots:

Stallion and Tres Outlaws and I, we have that [unspoken ethical code]. We have guys that are brothers that work together. If somebody needs leather, we'll loan them. If a machine breaks, we'll loan them. Because they know what they make. I'm not going to make what they make. (Interview with author 2010) 
Such tacit cooperation underpins this distinctive craft-based form of network retention (cf. Glückler 2007) - via input materials, machinery and designs.

Further agglomeration tendencies relate to the centrality of skilled labor and proximity to input materials - both legacies of mass manufacturing. Without formal training in bootmaking the new collector enthusiasts who sought to set up niche labels could not quickly or easily make boots themselves. The only way to tap into necessary skills was to locate in Texas, especially El Paso, where there were surviving (although ageing) bootmakers from the height of mass manufacturing, and where family traditions of skills transfer had survived. In the 1990s, when the key niche workshops emerged, cross-border commuting was still possible, enabling extended families with long histories in bootmaking to continue to reside in Juarez but work in El Paso. Later, amidst much-publicized drug cartel violence, President G.W. Bush tightened border controls, and many of those families, interviewed for this research, found themselves split across the border, or chose to leave behind houses and relatives in Juarez to pursue bootmaking livelihoods in El Paso.

In such new enterprises workers' rates of pay remained respectable for manual work, relatively higher than during the mass-manufacturing era, and much higher than for workers making factory-made boots in China and Mexico. Rates of unionization nevertheless remain low; with tacit (and often fluid) agreements in micro-enterprises replacing formal workplace negotiations. Supplanting the traditional role of collective organization of labor has been the institution of the Latino extended family - with enterprises either wholly owned by them or staffed by bootmakers from related families who negotiate working conditions, pay and hours according to an informal "code of conduct," using socially-inscribed notions of "how things should be done.” Important to many bootmakers, now in their 60s or even 70s, and considered "master craftsmen," has been to 
leverage upon their unique skills to negotiate more reasonable working hours - limiting the length of days and numbers of days worked per week to suit shifting priorities of time spent with families and friends. The better-known master bootmakers have negotiated higher rates of pay and fewer hours of work to the equivalent of only 4-5 days per fortnight. Some workshop owners interviewed for this research complained about the resulting rarity of labor and the degree of familial "closed shop,” which further limited volume. Yet an awkward compromise of sorts had emerged - accommodated by the fact that customers ordering bespoke boots are willing to wait many months for the finished product, and that rarity value and the cult of the known manual artisan pertains to this artful commodity. Delays became inevitable, but rather than being fatal, served to buttress rarity value and the perception of a product made with "authentic" methods and manual labor.

Alongside the materiality of embodied skills, the importance of proximity to raw materials traders also shaped the geography of craft production. Leather traders were originally attracted to El Paso because of its concentration of bootmakers and confluence of transport routes across the border - they moved to and consolidated in El Paso in the 1960s and 1970s, at the height of the factory system, in tandem with the industry contracting elsewhere across Texas. In the era of cultural capitalism the presence of established quality leather traders then became a "retention mechanism" (Glückler 2007, 624) enabling craft bootmakers privileged access to the finest raw materials. Speed of access to the key input material was less important (given that bespoke boot customers are used to waiting many months for their orders), than was the on-going ability to feel, smell and manipulate the leather with the hands before purchase. With small production runs, leathers are procured in comparatively tiny quantities, with price less a concern than quality. For custom bootmakers whose reputation is based on craft, quality and individuality, 
seeing and feeling skins (with all their animal variations and inconsistencies) before procurement offsets risks of purchasing at a distance and receiving lower quality, imperfect leathers. According to Rocketbuster: "you can get leather anywhere, but here you can actually go look at it and touch it... here we can go and touch everything. Mum and Pop boot shops around the country have to order stuff and hope for the best” (Interview with author, 2010). Proximity to materials that in turn require haptic engagement further fuelled agglomeration tendencies in El Paso. The result is a modest cluster on South Cotton Street and in nearby industrial estates on the eastside of El Paso - the city's historic lower-rent and mostly Mexican district; many a mere hundred yards from the US-Mexican border, where small factory and warehouse spaces associated with the city's boomtime railway era are available at low rent - a remnant of where the industry originally concentrated in the 1920s (Figure 3).

Meanwhile, small custom workshops retain significant leather stocks in closely guarded backrooms - sometimes huge inventories of materials sourced intermittently when highly variable supply chains open up. In a direct parallel to other new and revived craft industries such as fine woodworking and lutherie (cf. Dudley 2014), large inventories are essential - both a financial risk, and necessary to maximize creative design possibilities, storing materials of all manner of sources and colors, for future possible use. In the case of one workshop, they literally inherited leather supplies from a retired bootmaker worth tends of thousands of dollars - a rare bequest enabling use of skins now impossible to source, enhancing vintage cache and making a direct material connection with the industry's past.

By 2001 El Paso newspapers had refined the message - no longer a mass manufacturing city, it was a center of craft-based cultural production, the "hand-made boot capital of the world" (Kolenc 2001, 2E). This contemporary craft cluster still depends on the kinds of materialities that 
saw the emergence of mass manufacturing in an earlier phase of capitalism: access to skilled labor with requisite, slowly-accrued haptic skills; retention of archaic production methods (though redeployed as a means to artful creative expression); and proximity to the key material input - leather. El Paso was where the leather was and still is traded, enabling bootmakers to feel the skins first, before buying, and it is where skilled craftspeople from a previous era of mass manufacturing still live and work. Whereas firms moved to El Paso in the 1960s and 1970s for cheap, skilled manufacturing labor, in the era of cultural capitalism they locate in El Paso to be proximate to leather supplies, to access (now rare) remnants of that skilled migrant labor, and to tap into mythologies of a frontier place of artisanal making that "authenticate” the product.

\section{Conclusions}

Against the apparent abstract immateriality of much evolutionary economic geography, the physical world still matters. If, as Bottazi et al $(2007,652)$ suggest, "the spatial distribution of economic activities is likely to depend on the intrinsic features of space itself-features that look very much like endowments or at least 'slow' variables... which change on a time scale much longer than the scale over which micro decisions occur," then many such features are at their core, material. Evolution of methods of physical production is place- and path-dependent (cf. Dosi 1997), and shaped by on-going tensions between, on the one hand, skilled manual work, and on the other, corporate tactics to mechanize and split tasks (cf. Frances 1993). Meanwhile labor process is, in successive iterations, shaped by inheritance of embodied and material conditions - by the spaces of work, by place associations, by necessary machinery and skills (cf. Massey 1984; Gough 2003). At the core is the lock-in of product design and necessary 
component materials. Here lock-in signals not so much a market "inefficiency” (cf. Martin and Sunley 2006) but a continuity with the past that in an era of cultural capitalism confers “authenticity,” and that acts as a source of leverage for manual workers - with their accompanying haptic skills embedded in the hands.

For economic geography more broadly, the kind of evolutionary approach sought here - with a dual focus on labor process and materiality - opens up scope to connect contemporary cultural capitalism (Žižek 2010:356) to the phases that preceded it: to for instance rethink creative work in light of legacies in manufacturing and heavy industry (Jayne 2004; Warren and Gibson 2011; Hatch 2013). Adding to timeliness is the renewed interest in craft modes of production (Jakob 2013; Luckman 2015) and debates about resilience of maligned manufacturing cities amidst the contradictions of global capitalism (cf. Bristow 2010; Clark 2014). In an era where more and more work tasks are automated, of critical import is the manner in which manual tasks become a site of value (within cultural capitalism), and of new forms of struggle, based on the retention of valued haptic skills (Warren 2014). Arguably nowhere is haptic skill more visible currently than in the rise of craft-based production. In such circles there is intense renewed interest in what are perceived to be archaic or pre-globalization labor processes (Luckman 2013). Amidst the everencroaching digital mediation of everyday life, consumers who have "grown weary of the fabricated authenticity claims that saturate the landscape of commodity consumption” (Goldman and Miller 2013, np) instead value artisanal skill, and personal relationships with makers, preferring “old”, “analogue” ways of making things. Putatively archaic labor processes blacksmithing, leather-tooling, beer brewing, hand-drawn fashion advertising - are being revived or rediscovered. In the rush to proclaim such revivals as new creative investment pathways or as 
panaceas for industrial decline, it is worth pausing to document the particular place- and pathdependent histories from which they emerge.

The case of El Paso supports the overall argument that forms of craft production must be understood as having evolved in place because of a complex mix of legacies, material inheritances, underlying geographical conditions, waves of investment and negotiations between firms and workers over labor process. In El Paso, bootmaking has transitioned from mass manufacture to craft-based cultural capitalism, and has been repositioned as creative rather than routine. Bootmakers need the credibility that comes with this city's mythologies of frontier cowboy history and bespoke manual production; they need workers with haptic skills to fashion complex pieces by hand; and they need to feel exotic leather supplies with their own hands before ordering expensive supplies.

From a seemingly obscure, if iconic, example, there are broader implications. First, tracing the economic geography of craft production requires greater recognition of deeper, place-specific inheritances - and understanding of the manner in which logics of cultural capitalism intersect with uneven geographies of growth and decline from the mass-manufacturing era. Histories of manual labor, skills transfer, product design, and trade in key materials bestow select cities and regions with traits that provide the means for later reorientation (cf. Hudson 2005). Apparently redundant skills, production methods, machinery and supplies can linger and provide future opportunities. Nevertheless, this may only occur in certain places, and for certain forms of material production - where strong cultural place associations, path dependencies and material inheritances are present. 
Second, materiality is a key factor. The material basis of production ought to feature more prominently in evolutionary analysis. In this case a commodity's core design and stability of type form illustrated the role material factors can play in the evolutionary concept of lock-in (cf. Molotch 2005; Martin 2010). Meanwhile other materialities included haptic, tactile skills embodied and embedded in workers' bodies (cf. Sennett 2008), and the proximity to trading networks for the key input material - for which provenance and quality are a premium.

Finally, this case supports the argument for a grounded and critical evolutionary approach (Barnes and Sheppard 2010), premised on understanding capitalism as ever contradictory and as experienced in unfurling and contingent fashion by workers and firms (cf. MacKinnon et al 2009; Martin 2010; Hudson 2012). If evolutionary economic geography is to prove useful in interpreting new forms of craft production, it must be prepared to intersect with closer analysis of labor process and accompanying embodied skills, technologies, machines and materials, and with the logics of cultural capitalism from which renewed interest in craft springs. Opportunities for craft-based production are of course deeply shaped by macroeconomic forces (Weller 2014), but they are also manifest in particular, geographically embedded trajectories that require systematic analysis (cf. Rantisi and Leslie 2010). A seemingly particular example of craft-based production thus illuminates deeper paradoxes of contemporary political economy: of how labor process, product design, materials and mythology persist and evolve amidst substantial wider forces of change.

Acknowledgments: I thank Naomi Riggs for invaluable research assistance in Texas; Roberta Comunion, Robert Hassink, James Murphy and the journal's anonymous referees for 
constructive feedback on earlier drafts; and Chantel Carr, Nick Skilton and Andrew Warren for on-going dialog and collaborations around themes of manufacturing, craft, and labor. 


\section{References}

Bakker, K. and Bridge, G. 2006. Material worlds? Resource geographies and the 'matter of nature’. Progress in Human Geography 30:5-27.

Banks, M. 2010. Craft labour and creative industries. International Journal of Cultural Policy 16:305-321.

Barnard, P. and Shapiro, S. 2014. Editors’ introduction, to Guéry, F. and Deleule, D. 2014. The Productive Body. London: Zero Books.

Barnes, J.R. 2014. Aspirational Economies of Self and City: The Values and Governance of Independent Crafters in Columbus, Ohio. PhD Thesis, Department of Geography, Ohio State University.

Barnes, T.J. and Sheppard, E. 2010. 'Nothing includes everything': towards engaged pluralism in Anglophone economic geography. Progress in Human Geography 34:193-214.

Beard, T. and Arndt, J. 1992. The Cowboy Boot Book. Salt Lake City: Gibbs Smith.

Bennett, J. 2010. Vibrant Matter: A Political Ecology of Things. Durham: Duke University Press.

Berndt, C. 2013. Assembling market b/orders: violence, dispossession, and economic development in Ciudad Juárez, Mexico. Environment and Planning A 45: 2646-2662.

Birtchnell, T. and Urry, J. 2013. Fabricating futures and the movement of objects. Mobilities 8:388-405.

Boschma, R. and Frenken, K. 2009. Some notes on institutions in evolutionary economic geography. Economic Geography 85:151-158.

Bottazzi, G., Dosi, G., Fagiolo, G. and Secchi, A. 2007. Modeling industrial evolution in geographical space. Journal of Economic Geography 7:651-672.

Bourdieu, P. 1984. Distinction: a Social Critique of the Judgement of Taste. London: Routledge. 
Bristow, G. 2010. Resilient regions: re-‘place’ing regional competitiveness. Cambridge Journal of Regions, Economy and Society 3:153-167.

Bryson, J.R. and Ronayne, M. 2014. Manufacturing carpets and technical textiles: routines, resources, capabilities, adaptation, innovation and the evolution of the British textile industry. Cambridge Journal of Regions, Economy and Society 3:471-488.

Bull, D. 2000. Hillbilly Hollywood: The Origins of Country \& Western Style. New York: St. Martins Press.

Burchell, J. 1977. Cowboy boots? This is the place, El Paso Times, 19 November, B1-3.

Causey, J. 2014. Brooklyn Makers: Food, Design, Craft, and Other Scenes from the Tactile Life. Chronicle, San Francisco.

Carr, C. and Gibson, C. 2015. Geographies of making: rethinking materials and skills for volatile futures. Progress in Human Geography DOI: 10.1177/0309132515578775.

Clark, J. 2014. Manufacturing by design: the rise of regional intermediaries and the reemergence of collective action. Cambridge Journal of Regions, Economy and Society 3:433-448.

Coe, N. 2013. Geographies of production III: making space for labour. Progress in Human Geography 37:271-284.

Comunian, R. 2011. Rethinking the creative city: the role of complexity, networks and interactions in the urban creative economy. Urban Studies 48:1157-1179.

Cook, I. 2004. Follow the thing: papaya. Antipode 36: 642-664.

Cook, I.J., Evans, J., Griffiths, H., Morris, R. and Wrathmell, S. 2007. 'It's more than just what it is’: defetishising commodities, expanding fields, mobilising change. Geoforum 38:11131126. 
David, P.A. 1985. Clio and the economics of QWERTY. The American Economic Review 75:332-337.

DeLano, S. and Rieff, D. 1981. Texas Boots. New York: Penguin.

DeLyser, D. 1999. Authenticity on the ground: engaging the past in a California ghost town. Annals of the Association of American Geographers 89: 602-632.

Dosi, G. 1997. Opportunities, incentives and collective patterns of technological change. Economic Journal 107: 1530-1547.

Dudley, K.M. 2014. Guitar Makers: The Endurance of Artisanal Values in North America. Chicago: University of Chicago Press.

Farman, I. 1996. Standard of the West: The Justin Story. Fort Worth: Texas Christian University Press.

Frances, R. 1993. The Politics of Work: Gender and Labour in Victoria, 1880-1939. Melbourne: Cambridge University Press.

George-Warren, H. and Freedman, M. 2006. How the West Was Worn: a History of Western Wear. New York: Abrams.

Gibson, C. 2003. Cultures at work: why 'culture’ matters in research on the 'cultural' industries. Social and Cultural Geography 4:201-215.

Gibson, C. 2005. Recording studios: relational spaces of creativity in the city. Built Environment 31: 258-273.

Gibson, C. 2013. The global cowboy: rural masculinities and sexualities. In Sexuality, Rurality and Geography, ed. A. Gorman-Murray, B, Pini and L. Bryant, 199-218. Lanham MD: Lexington. 
Gibson, C. 2014. Souvenirs, materialities and animal encounters: following Texas cowboy boots. Tourist Studies 14:286-301.

Glückler, J. 2007. Economic geography and the evolution of networks. Journal of Economic Geography 7:619-634.

Goldman, R. and Miller, A. 2013. Searching for value in the wastelands of commodity fetishism. Fast Capitalism 10: http://www.uta.edu/huma/agger/fastcapitalism/10_1/goldman10_1.html

Gough, J. 2003. Work, Locality and the Rhythms of Capital. London: Continuum.

Greco, L. and Di Fabbio, M. 2014. Path-dependence and change in an old industrial area: the case of Taranto, Italy. Cambridge Journal of Regions, Economy and Society 7:413-431.

Guéry, F. and Deleule, D. 2014. The Productive Body. London: Zero Books.

Hassink, R., Klaerding, C. and Marques, P. 2014. Advancing evolutionary economic geography by engaged pluralism. Regional Studies 48:1295-1307.

Hatch, C. 2013. Competitiveness by design: An institutionalist perspective on the resurgence of a mature industry in a high wage economy. Economic Geography 89: 261-284.

Hobsbawm, E. 2013. Fractured Times: Culture and Society in the $20^{\text {th }}$ Century. London: Little, Brown.

Hockey, J. and Allen-Collinson, J. 2009. The sensorium at work: the sensory phenomenology of the working body. The Sociological Review 57:217-239.

Hodgson G. 1994. The return of institutional economics, in The Handbook of Economic Sociology, ed. N.J. Smelser and R. Swedberg. Princeton, NJ: Princeton University Press. Hogue, A. 1977. Boots provide economic ‘kick’. El Paso Times 5 June, C1. 
Hudson, R. 2004. Conceptualizing economies and their geographies: spaces, flows and circuits. Progress in Human Geography 28:447-471.

Hudson, R. 2005. Rethinking change in old industrial regions: reflecting on the experiences of North East England. Environment and Planning A 37:581-596.

Hudson, R. 2012. Critical political economy and material transformation. New Political Economy 17: 373-397.

Hutton, T. 2006. Spatiality, built form, and creative industry development in the inner city. Environment and Planning A 38:1819-1841.

Ingold, T. 2010. The textility of making. Cambridge Journal of Economics 34: 91-102.

Jakob, D. 2013. Crafting your way out of the recession? New craft entrepreneurs and the global economic downturn. Cambridge Journal of Regions, Economy and Society 6:127-140.

Jayne, M. 2004. Culture that works? Creative industries development in a working-class city. Capital \& Class 28:199-210.

J.B. Hill Boot Company. 2010. Company brochure. JB Hill, El Paso.

Kolenc, V. 2001. Bootmakers face slow growth. El Paso Times 15 April, E-1-2E.

Lash, S. and Urry, J. 1994. Economies of Signs and Space. London: Sage.

Latham, A. and McCormack D.P. 2004. Moving cities: rethinking the materialities of urban geographies. Progress in Human Geography 28: 701-724.

Lee, R. 2006. The ordinary economy: tangled up in values and geography. Transactions of the Institute of British Geographers 31:413-432.

Leslie, D. and Reimer, S. 2006. Situating design in the Canadian household furniture industry. Canadian Geographer 50:319-341.

Luckman, S. 2012. Locating Cultural Work. London: Palgrave Macmillan. 
Luckman, S. 2013. The aura of the analogue in a digital age: women’s crafts, creative markets and home-based labour after Etsy. Cultural Studies Review 19:249-70.

Luckman, S. 2015. Craft and the Creative Economy. London: Palgrave Macmillan.

MacKinnon, D., Cumbers, A., Pike, A., Birch, K. and McMaster, R. 2009. Evolution in economic geography: institutions, political economy, and adaptation. Economic Geography 85:129-150.

Markusen, A. 2010. Organizational complexity in the regional cultural economy. Regional Studies 44:813-828.

Martin, R. 2010. Rethinking regional path dependence: beyond lock-in to evolution. Economic Geography 86:1-27.

Martin, R. and Sunley, P. 2006. Path dependence and regional economic evolution. Journal of Economic Geography 6:395-438.

Martínez, O.J. 1978. Border Boom Town: Ciudad Juarez Since 1848. Austin: UT Press.

Massey, D. 1984. Spatial Divisions of Labour. London: Macmillan.

McDowell, L. 2008. Thinking through work: complex inequalities, constructions of difference and trans-national migrants. Progress in Human Geography 32:491-507.

McDowell, L. 2015 The lives of others: body work, the production of difference, and labor geographies. Economic Geography 91:1-23.

Melachroinos, K.A. and Spence, N. 2001. Conceptualising sunk costs in economic geography: cost recovery and the fluctuating value of fixed capital. Progress in Human Geography 25:347-364.

Mitchell, T. 2008. Rethinking economy. Geoforum 39:1116-1121.

Mitchell, T. 2011. Carbon Democracy: Political Power in the Age of Oil. London: Verso. 
Molloy M. and Larner W (2013) Fashioning Globalisation: Design, Working Women and the Cultural Economy. Oxford: Wiley-Blackwell.

Molotch, H. 2005. Where Stuff Comes From. New York: Routledge.

Müller, K., Rammer, C. and Trüby, J. 2009. The role of creative industries in industrial innovation. Innovation: Management, Policy \& Practice 11:148-168.

Plummer, P. and Sheppard, E. 2006. Geography matters: agency, structures and dynamics at the intersection of economics and geography. Journal of Economic Geography 6:619-637.

Pratt, A. 2004. The cultural economy: a call for spatialized 'production of culture' perspectives. International Journal of Cultural Studies 7:117-128.

Pruitt, P. 1976. Customs probes Tony Lama firm. El Paso Times 4 June, 11-C.

Rantisi, N.M. and Leslie, D. 2010. Materiality and creative production: the case of the Mile End neighborhood in Montréal. Environment and Planning A 42:2824-2841.

Rantisi N.M., Leslie D. and Christopherson S. 2006. Placing the creative economy: scale, politics, and the material. Environment and Planning A 38:1789-1797.

Rutherford, T.D. and Holmes, J. 2014. Manufacturing resiliency: economic restructuring and automotive manufacturing in the Great Lakes region. Cambridge Journal of Regions, Economy and Society 7:359-378.

Scott, A.J. 1988. New Industrial Spaces. London: Pion.

Scott, A.J. 2000. The cultural economy of Paris. International Journal of Urban and Regional Research 24:567-582.

Scott, A.J. 2006a. Creative cities: conceptual issues and policy questions. Journal of Urban Affairs 28:1-17. 
Scott, A.J. 2006b. Entrepreneurship, innovation and industrial development: geography and the creative field revisited. Small Business Economics 26:1-24.

Sennett, R. 2008. The Craftsman. New Haven: Yale University Press.

Thody, L. 2014. From working class to hipster flash: locating Newcastle City in Newcastle Brown Ale. Visual Culture in Britain 15:173-191.

Thomas, N., Harvey, D.C. and Hawkins, H. 2013. Crafting the region: creative industries and practices of regional space. Regional Studies 47:75-88.

Toila-Kelly, D.P. 2013. The geographies of cultural geography III: material geographies, vibrant matters and risking surface geographies. Progress in Human Geography 37:153-160.

Tomlinson, P.R. and Branston, J.R. 2014. Turning the tide: prospects for an industrial renaissance in the North Staffordshire ceramics industrial district. Cambridge Journal of Regions, Economy and Society 7:489-507.

Walker, M.A. 2007. The cultural economy of a border renaissance: politics and practices in the city. Space and Polity 11:185-200.

Warren, A. 2014. Working culture: the agency and employment experiences of non-unionized workers in the surfboard industry. Environment and Planning A 46:2300-2316.

Warren, A. 2015. Crafting masculinities: gender, culture and emotion at work in the surfboard industry. Gender, Place and Culture DOI: 10.1080/0966369X.2014.991702

Warren, A. and Gibson, C. 2011. Blue-collar creativity: reframing custom-car culture in the imperilled industrial city. Environment and Planning A 43:2705-2722.

Warren, A. and Gibson, C. 2013. Crafting regional cultural production: emergence, crisis and consolidation in the Gold Coast surfboard industry. Australian Geographer 44:365-381. 
Warren, A. and Gibson, C. 2014. Surfing places, surfboard-makers: craft, creativity and cultural heritage in Hawai'i, California and Australia. Honolulu: University of Hawaii Press.

Watson, A. 2013. Creating the right 'vibe': emotional labour and musical performance in the recording studio. Environment and Planning A 45:2904-2918.

Weller, S. 2007. Fashion as viscous knowledge: fashion's role in shaping trans-national garment production. Journal of Economic Geography 7:39-66.

Weller, S. 2014. Creativity or costs? Questioning New Zealand's fashion success: a methodological intervention. Journal of Economic Geography 14:721-737.

Whatmore, S. 2006. Materialist returns: practicing cultural geography in and for a more-thanhuman world. Cultural Geographies 13:600-609.

Wilson, D. 1991. Urban change, circuits of capital, and uneven development, The Professional Geographer 43: 403-415.

Wright, M.W. 1997. Crossing the factory frontier: gender, place and power in the Mexican Maquiladora. Antipode 29:278-302.

Žižek, S. 2010. Living in the End Times. London: Verso.

Zukin, S. 2010. Naked City: the death and life of authentic urban places. New York: Oxford University Press. 